$$
\begin{aligned}
& \text { ラジカル窒化による Alloy } 718 \text { の疲労特性改善について }
\end{aligned}
$$

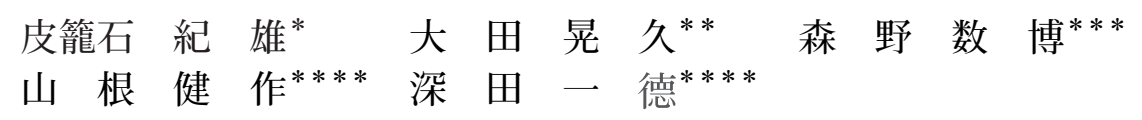

\title{
Improvement of Fatigue Properties of Alloy 718 by Radical Nitriding
}

by

\author{
Norio Kawagoishi ${ }^{*}$, Akihisa Ohta ${ }^{* *}$, Kazuhiro Morino ${ }^{* * *}$, \\ Kensaku Yamane ${ }^{* * * *}$ and Kazunori FuKADA ${ }^{* * * *}$
}

\begin{abstract}
In order to improve the fatigue strength of a nickel base super alloy, Alloy 718 , by nitriding, and make clear the crack initiation site in the nitrided alloy, fatigue tests of the plain specimen were carried out under rotating bending. The suitable treatment condition of radical nitriding was investigated from the view points of thickness of the compound layer and strength of the base alloy in combination of nitriding with aging conditions. The selected condition was the combination of treatments of nitriding at $570^{\circ} \mathrm{C}$ for $20 \mathrm{~h}$ after aging at $720^{\circ} \mathrm{C}$ for $8 \mathrm{~h}$ and then at $620^{\circ} \mathrm{C}$ for $4 \mathrm{~h}$ in consideration of practical application. By this treatment, compound layer was formed on the specimen surface with the thickness of about $10 \mu \mathrm{m}$ without softening of the base alloy. Crack initiation was markedly suppressed by the compound layer, causing the increase in fatigue strength. A crack initiated at the base alloy beneath the compound layer. The initiated crack propagated gradually to both directions of the compound layer and the base alloy, though the crack in the compound layer showed a brittle manner.
\end{abstract}

Key words : Fatigue, Alloy 718, Radical nitriding, Rotating bending, Crack initiation, Crack propagation, Compound layer

\section{1 緒言}

材料の高機能化や長寿命化を目的に各種の表面改質技 術が適用されている.1) 4)著者らも，高強度鋼を中心に窒 化やAIP コーティング，さらにはそれらを組み合わせた 複合处理を行い, 耐摩耗性, 耐食性, 疲労特性への影響 を検討した.5) 11) その中で, ラジカル窒化法は, 12) 化合物 層の生成を制御できること, 表面の荒れは小さいことに 加え, 他の窒化法に比べ低い温度で堂化できるという特 長を有し, 耐摩耗性や疲労特性の改善に有効であること を報告した。また本堂化法は，ステンレス鋼や $\mathrm{Ni}$ 基超 合金のような表面に強固な不動態被膜が形成される材料 にも有効であり，中でも本窒化法の特長である低温での 処理は，焼入れや時効硬化で高強度化した材料に窒化処 理する際に問題となる母材の軟化を抑制できるという点 て優れている，この点につき，著者らは，本窒化法を $\mathrm{Ni}$ 基超合金の一つである Alloy 718 に適用し，得られた最 大厚さは $10 \mu \mathrm{m}$ 程度と薄いものの, 化合物層の形成, そ れによる耐摩耗性と室温での引張圧縮および回転曲げ疲 労特性が改善されること, その理由は化合物層によるき 裂発生の抑制であることを確認した.9) 11) しかし，き裂 発生の抑制効果を高めるには化合物層を厚くする必要が あり，その場合，窒化温度を高く，あるいは時間を長く
せざるを得ず，处理の温度と時間によっては母材の軟化 が生じる。午の場合，き裂発生は抑制できても伝ば抵抗 は低下し, 期待通りの疲労強度向上は得られないことが あることを報告した。また，試験片表面の疲労被害扰上 び破面の観察を行い，窒化材に打けるき裂発生箇所は， 試験片表面であると判断したが，化合物層が薄く，厳密 には化合物層の表面かあるいは化合物層と母材の界面の いずれであるかを特定するまでには至らなかった。

そこで本研究では, Alloy 718 の窒化において，母材の 軟化を生じさせずに化合物層を厚くし, 疲労特性を改善 するための時効处理と窒化処理の条件を検討することと， 窒化材に打けるき裂発生箇所を明らかにすることを目的 に回転曲げ疲労試験を行った。

\section{2 材料，試験片および実験方法}

用いた材料は市販の Ni 基超合金 Alloy 718 （直径 $15 \mathrm{~mm} ）$ の丸棒であり，その化学成分は $0.02 \mathrm{C}, 0.11 \mathrm{Si}$, $0.12 \mathrm{Mn}, 0.009 \mathrm{P}, 0.001 \mathrm{~S}, 52.64 \mathrm{Ni}, 18.67 \mathrm{Cr}, 3.09 \mathrm{Mo}$, $0.09 \mathrm{Co}, 0.01 \mathrm{Cu}, 0.66 \mathrm{Al}, 0.90 \mathrm{Ti}, 0.0041 \mathrm{~B}, 5.12 \mathrm{Nb}+\mathrm{Ta}$, $\mathrm{Fe}$, bal. (mass\%) である. 素材は, $982^{\circ} \mathrm{C}, 1 \mathrm{~h}$ で溶体化した 状態で納入されたものであり, 平均結晶粒径は約 $18 \mu \mathrm{m}$ であった. 先ず予備実験として, 納入材に対し, 先の研 究で確認したラジカル窒化炉の使用温度と実用的な処理

\footnotetext{
$\dagger \quad$ 原稿受理 平成 23 年 3 月 22 日 Received Mar. 22, 2011 C 2011 The Society of Materials Science, Japan

* 正 会 員 鹿児島大学大学院理工学研究科 =890-0065 鹿児島市郡元, Dept. of Mech. Eng., Kagoshima Univ., Korimoto, Kagoshima, 890-0065

** 鹿児島大学大学院理工学研究科 ＝890-0065 鹿児島市郡元, Dept. of Mech. Eng., Kagoshima Univ., Korimoto, Kagoshima, 890-0065

*** 正 会 員 徳山高等専門学校機械電気工学科 =745-8585 周南市学園台, Tokuyama College of Tech., Gakuendai, Shunan, 745-8585

$* * * *$ 正 会 員 鋼鈑工業(株) †744-0011 下松市西豊井, Kohan Kogyo LTD, Nishi-toyoi, Kudamatsu, 744-0017
} 
時間の中で化合物層が最も厚くなる $570^{\circ} \mathrm{C}, 20 \mathrm{~h}$ の窒化条 件を選び，その条件をべースに母材が軟化しない時効条 件を各種検討した。なおこの予備実験では，母材の硬さ 変化に及ぼす熱处理の温度と時間の影響を調べることを 目的としているので，実際の窒化处理は行っていない。

Fig. 1 に予備実験の中から選んだ本研究での時効条件

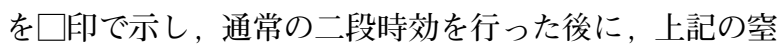
化条件に相当する時効処理を行った場合の硬さ変化を 印で示す、印で示した条件では，母材は過時効状態に

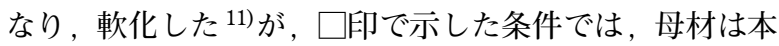
材に通常適用する二段時効処理 $\left(720^{\circ} \mathrm{C}, 8 \mathrm{~h}\right.$ 加熱保持の後 さらに $621^{\circ} \mathrm{C}, 8 \mathrm{~h}$ の時効）材と同等の硬さ (約 $500 \mathrm{HV}$ ) が得られる。

窒化処理は, 先に報告した結果 ${ }^{9)}$ 11) と同様, 時効後, 水素ガス扰よびアンモニアガス中で行った，以下では， 時効処理のままの材料を時効材, 本研究で適用した条件 により䇪化した材料を MN570 材と呼び，比較として先 に報告した通常適用する二段時効後，2 種の条件で堂化 した材料を $\mathrm{N} 570$ 材 $\left(570^{\circ} \mathrm{C}, 20 \mathrm{~h}\right.$ の窒化で母材は軟化, 化合物層厚さは約 $10 \mu \mathrm{m}), \mathrm{N} 500$ 材 $\left(500^{\circ} \mathrm{C}, 12 \mathrm{~h}\right.$ の窒化 で母材の軟化なし，化合物層厚さは約 $4 \mu \mathrm{m} ）$ と記す.

Fig. 2 に疲労試験片の形状と寸法を示す. $S-N$ 曲線を 求める際は, Fig. 2 の試験片を, き裂の発生と伝ぱ挙動を 求める場合は, 并の試験片の中央部に浅く鈍い部分切欠 き（深さ $0.1 \mathrm{~mm}$, 半径 $2.5 \mathrm{~mm}$ ) を加工したものを用いた. 機械加工は時効処理後に行った。 試験片表面はエメリー ペーパーによる研磨の後, 電解研磨で約 $20 \mu \mathrm{m}$ 除去して から, 時効材はそのまま, 窒化材はその後, 前述した条 件で窒化处理してから疲労試験に供した。表面き裂の観 察はレプリカ法で行い，き裂長さ $a$ は試験片表面に沿う 円周方向の長さで定義した。疲労試験は, 小野式回転曲

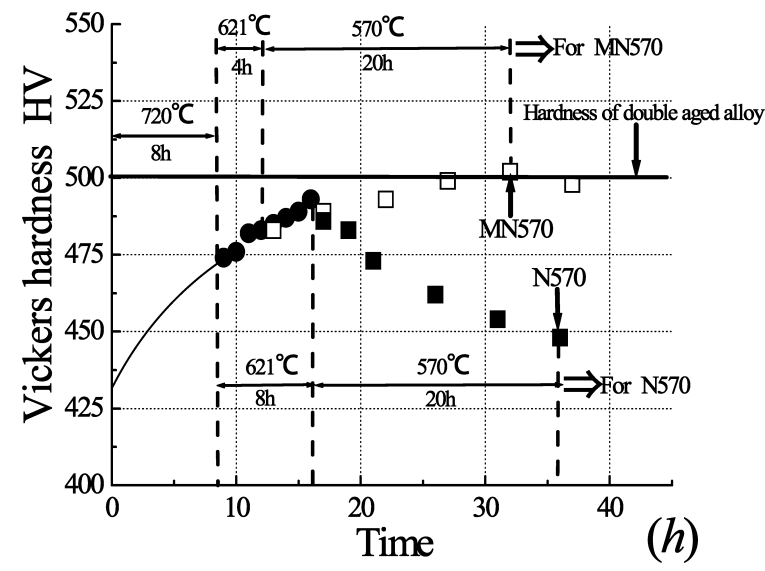

Fig. 1 Aging conditions.

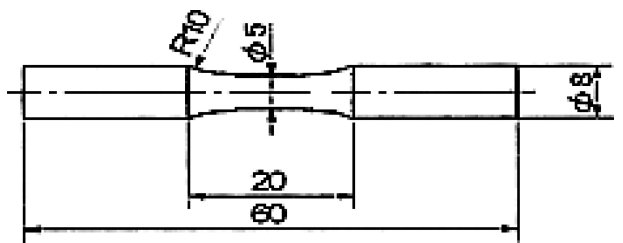

Fig. 2 Shape and dimensions of specimen (mm).
げ度労試験機（容量 $15 \mathrm{~N} \cdot \mathrm{m}$ ）を用いて室温，大気中で 行った。繰返し速度は約 $50 \mathrm{~Hz}$ である。

\section{$3 \cdot 1$ 窒化組織と硬さ分布}

Fig. 3 と Fig. 4 に, 窒化材の断面に打ける組織打よび 硬さ分布を示す. MN570 材は先の N570 材 ${ }^{11)}$ と窒化条 件を揃えているので, $10 \mu \mathrm{m}$ 程度と同じ厚さの化合物層 が生成され，穴の部分は $1200 \mathrm{HV}$ 前後と硬化している. また，内部への硬さ分布は，階段状の急な低下を示して おり，硬化は化合物層に限定され拡散層の存在は確認で きない，さらに窒素の拡散を EPMAでも観察したが，化 合物層以外では窒素を確認することはできなかった。し かし化合物層の極近傍で窒素の存在を精度良く特定する には至らなかったので，爷の詳細は不明であるが，存在す るとしても非常に薄いものと考えられる。そてて Fig. 1 に示した時効曲線で確認したように，N570 材の母材硬 さは時効材に比べ軟化しているのに対し，MN570 材の 場合，時効材の場合と同程度の硬さであり母材の軟化は みられない，以上のように，ここで選んだ時効と窒化の 条件であれば，母材を軟化させずに約 $10 \mu \mathrm{m}$ の化合物層 を生成できる。しかし緒言で述べたように本窒化法は化 合物層の生成を抑制できることも長所の一つであるが， 本材の場合これまでの検討では化合物層のない条件は得 られなかった。ただ、先の研究で明らかにしたように。 本材の場合化合物層の生成により，耐摩耗性だけでなく 疲労特性も改善された.9) 11)

Fig. 5 に各材の TEM 写真を示す. Fig. 1 の硬さ変化 から推察されたように, 時効材に比べ, 先の N570 材の析 出物は粗大化すなわち過時効状態になっているのに対し, MN570 材の場合の析出物の大きさは時効材のそれとほと

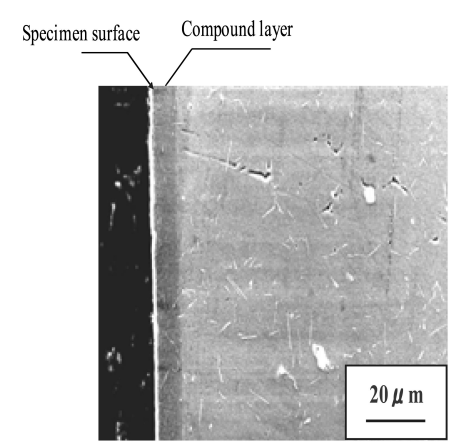

(a) N570

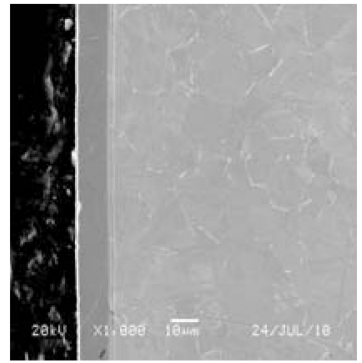

(b) MN570
Fig. 3 Microstructures of nitrided specimens.

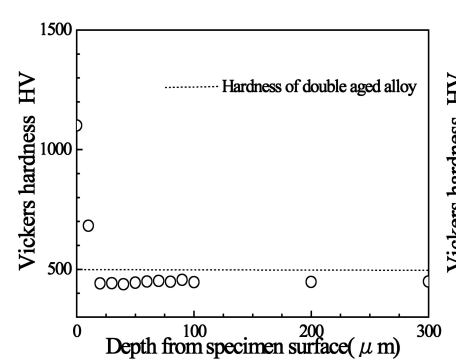

(a) N570

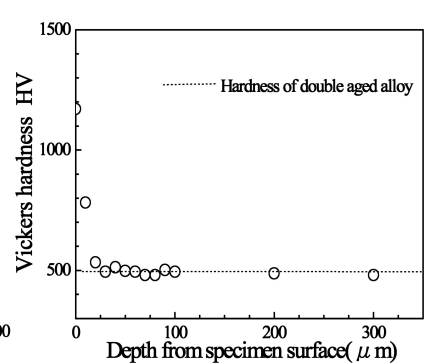

(b) MN570
Fig. 4 Distributions of nitrided specimens. 
んど変わらない. Table 1 に，時効材およびMN570 材と 同じ熱履歴を持つ材料（すなわち，MN570 材の窒化層 を除去した材料）の機械的性質を示す。新たな時効条件 によりわずかに高強度になっているが大きな差ではない．

\section{$3 \cdot 2$ 疲労特性}

Fig. 6 に, MN570 材の $S-N$ 曲線を示す，同図には先 に報告した時効材，N500 材打よび $\mathrm{N} 570$ 材の結果 ${ }^{11)}$ 示してある，窒化により疲労強度は上昇するが，化合物 層厚さはほぼ同じであっても，内部硬さが低下した N570 材よりそれのない MN570 材の方が疲労強度は高い。こ のことから，時効と窒化の条件が適切であれば，疲労強 度はさらに上昇することがわかる。

Fig. 7 と Fig. 8 は，MN570 材のき裂伝ぱ曲線とそのと きのき裂長さとき裂伝ぱ速度の関係である。これらの図に は時効材と $\mathrm{N} 570$ 材の結果 ${ }^{11)}$ も比較として示してある. MN570 材のき裂発生は，他の材料より遅れている。ま た，き裂伝ぱ速度は時効材のそれに比べき裂が短い間は やや遅いが，ある程度大きくなるとほほ等しく，N570 材 で生じた加速 ${ }^{11)}$ はられれい。このように窒化条件を同 時に考虑した時効条件を選べば，き裂伝ぱ抵抗を損なう ことなくき裂発生の抑制効果が得られ, 疲労特性は改善 される。

Fig. 9 は，MN570材の試験片表面で観察したき裂の レプリカ写真である。き裂は直線的に伝ぱし，ぜい性的 な特徴を有している。しかしこの場合，き裂を最初に確 認できたのは約 $20 \mu \mathrm{m}$ の長さであり，その後は Fig. 7 に

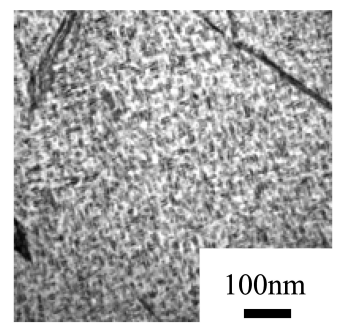

(a) Aged

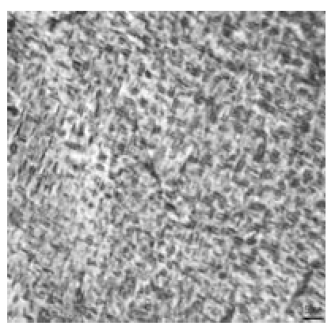

(b) N570

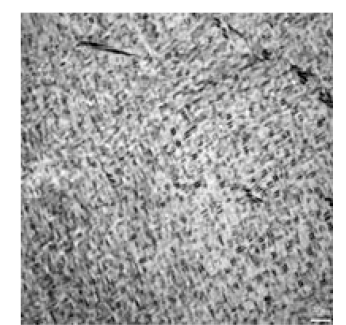

(c) MN570
Fig. 5 Microstructures observed by TEM.

Table 1 Mechanical properties.

\begin{tabular}{|c|c|c|c|c|}
\hline Aging condition & $\begin{array}{c}\sigma_{0.2} \\
(\mathrm{MPa})\end{array}$ & $\begin{array}{c}\sigma_{\mathrm{B}} \\
(\mathrm{MPa})\end{array}$ & $\begin{array}{c}\sigma_{\mathrm{T}} \\
(\mathrm{MPa})\end{array}$ & $\begin{array}{c}\phi \\
(\%)\end{array}$ \\
\hline $720^{\circ} \mathrm{C}, 8 \mathrm{~h} \rightarrow 621^{\circ} \mathrm{C}, 8 \mathrm{~h}$ & 1147 & 1372 & 2073 & 38.1 \\
\hline $\begin{array}{c}720^{\circ} \mathrm{C}, 8 \mathrm{~h} \rightarrow 621^{\circ} \mathrm{C}, 4 \mathrm{~h} \\
\rightarrow 570^{\circ} \mathrm{C}, 20 \mathrm{~h}\end{array}$ & 1120 & 1462 & 2417 & 40.9 \\
\hline
\end{tabular}

$\sigma_{0.2}: 0.2 \%$ proof stress, $\sigma_{\mathrm{B}}:$ Tensile strength $\sigma_{\mathrm{T}}$ : True fracture stress, $\phi$ : Reduction of area

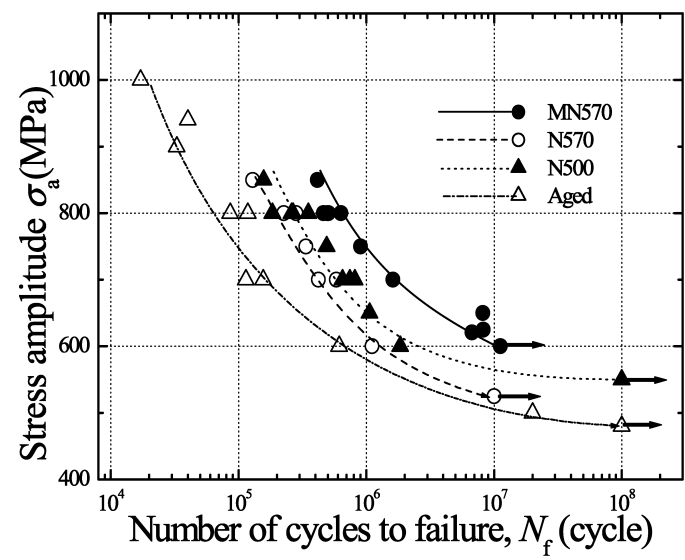

Fig. $6 S-N$ curves.

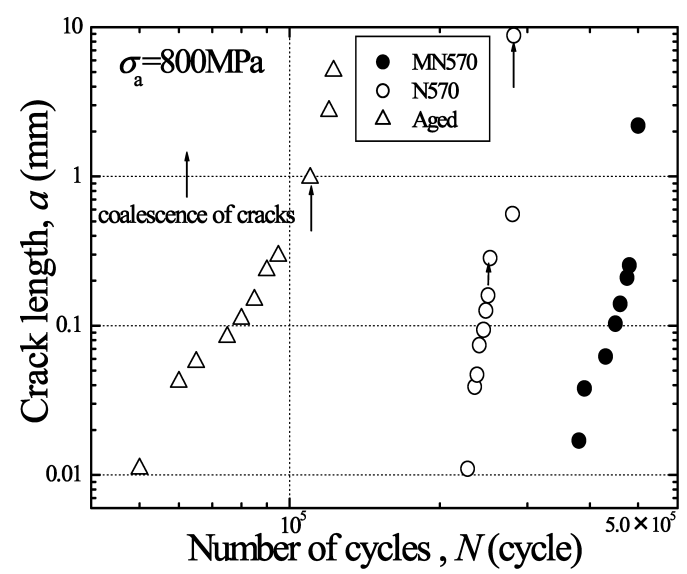

Fig. 7 Crack growth curves.

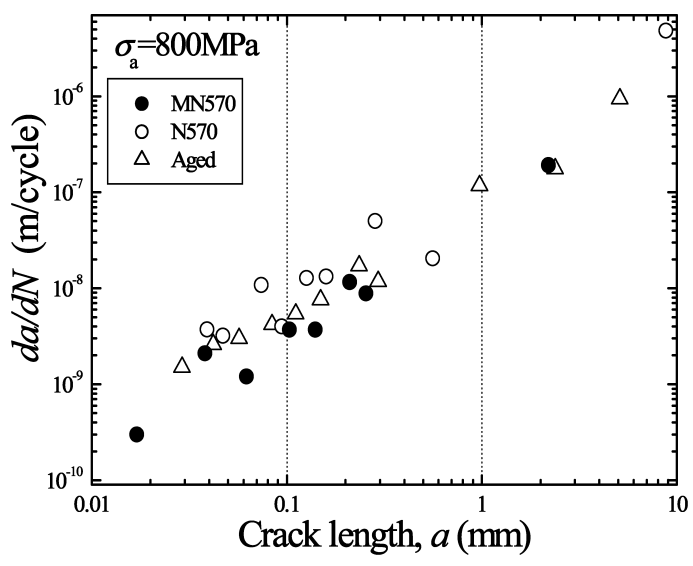

Fig. 8 Crack growth rate against crack length.

示したように，徐々に成長しておりぜい性き裂でみられ る急速伝ぱではない.

Fig. 10 は MN570材の破面写真である。き裂発生部 に注目すると，図中矢印で示すように，化合物層厚さに 相当する浅く平坦な領域が円周方向に確認され，Fig. 9 に示した表面観察におけるぜい性的なき裂の特徵に対応 している。しかし破面にみられる白い尾根状の模様は， き裂が表面の一箇所を起点に内部方向へ放射状に伝ぱし たことを示唆している。このことと, Fig. 7 の結果を併 せ考えると, 時効材と同様に, ${ }^{11)}$ 裂は試験片表面を起点 に発生したものと推測される。しかし化合物層が薄く， 


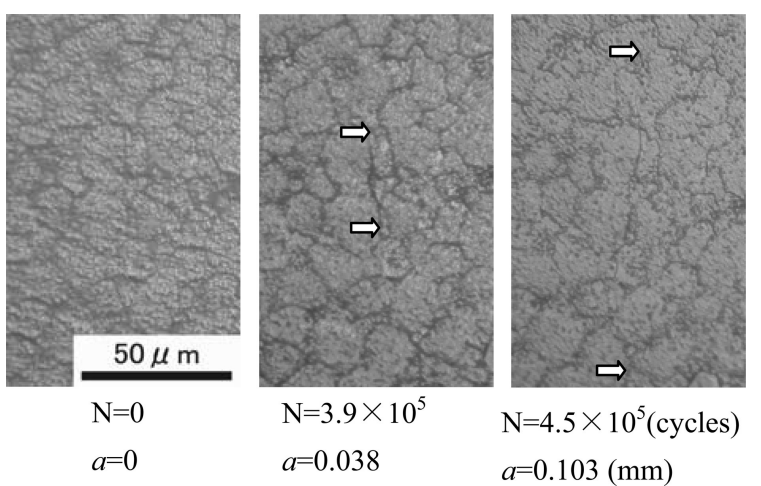

Fig. 9 Change in surface state of specimen due to stress repetitions (MN570, $\sigma_{\mathrm{a}}=800 \mathrm{MPa}, \Rightarrow$ crack tip, $\leftrightarrow$ axial direction)

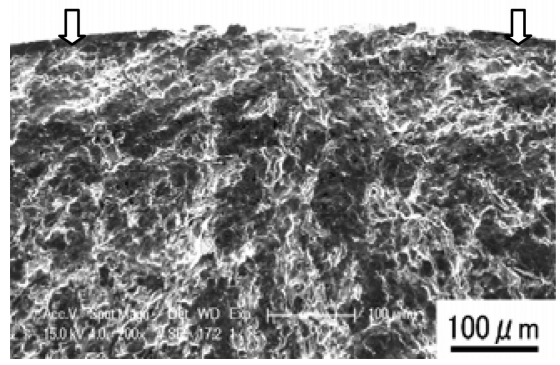

Fig. 10 Fracture surface (MN570).

正確な起点が化合物層表面であるのか，もしくは化合物 層と母材の界面であるのかを判別することは困難である. また表面改質材の疲労特性を調べたこれまでの研究でも， 例えばTi-6Al-4Vの窒化材に扔いて，表面またはその近 傍の窒化層でき裂は発生し，窒化層内を円周方向に伝ぱ してから内部方向に向かって伝ぱする場合 ${ }^{13)}$ と応力繰返 しのある時点で表面の化合物層とその下の窒化層で大き なき裂が瞬間的に発生し，内部方向へ伝ぱする場合があ る.14)また，窒化チタンの被膜を有する炭素鋼の場合，被 膜下の母材部に発生したき裂が成長し，ある長さに達し た後被膜が割れて表面き裂になる場合 ${ }^{15)}$ 等があり，材料 や表面処理法により異なる。このようなき裂発生箇所の 特定は，き裂発生機構の解明のみならず表面改質材の疲 労特性改善を検討する上で重要なことである。そこで，

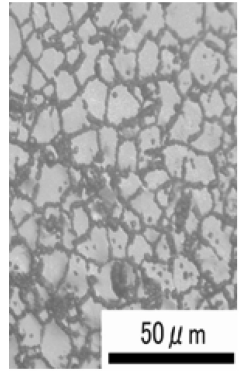

(a-1) Before EP

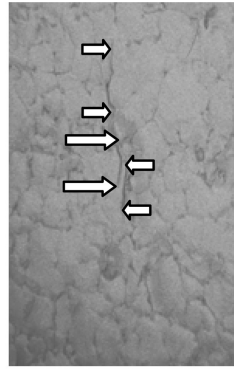

(a-2) After EP

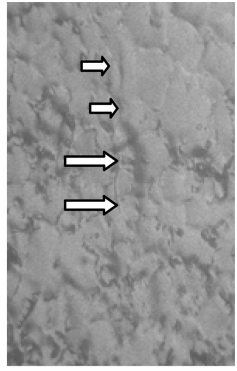

(a-3) After EP $(\mathrm{t} \simeq 30 \mu \mathrm{m})$ $a=0.023(\mathrm{~mm})$ $a=0$ $a=0.031$

(a) $N=2.5 \times 10^{5}$ (cycles)
このことを調べるため，応力繰返しの途中で試験片表面 を電解研磨で除去し，化合物層より内部における疲労被 害の状況を観察した。

Fig. 11 は，任意の応力繰返し後の表面状態と，その 表面を研磨した後の表面状態を示した例である。研磨前 は確認できなかったき裂が研磨により確認（Fig. 11 (a) の場合)，あるいは表面で測定されたき裂は研磨によりさ らに長いき裂として確認（Fig. 11 (b)の場合）できる. また，研磨をさらに続けるとき裂長さは短くなる。なお 組織とき裂との区別は，顕微鏡観察において組織境界等 はぼやけてみられたのに対し，き裂は比較的シャープで あったことから明確に確認できた，以上のことから，き 裂は化合物層に接する母材表面を起点に発生し，内部方 向へ成長すると共にある時点で表面の化合物層が割れ， 表面き裂になったものと考えられる。しかし化合物層の 割れは，前に示したき裂伝ぱ曲線や表面観察結果からわ かるように，ある時点で急に大きな長さのぜい性き裂が 生じるのではなく，少なくとも数十 $\mu \mathrm{m}$ 以下のき裂とし て化合物層表面に現れ，安定的に成長している。このこ とは，表面き裂はぜい性的に伝ぱしているものの，内部 へのき裂成長に支配された伝ぱであると考えられる。

Fig. 12 は, 上述した任意の応力繰返し後に電解研磨 する方法により化合物層を除去し，観察したき裂長さを もとに作成したき裂伝ぱ曲線（データ1点に対し 1 本の 試験片で求めたもの) である。同図には，研磨せずに 1 本 の試験片で連続的に求めた窒化材（MN570 材）の結果

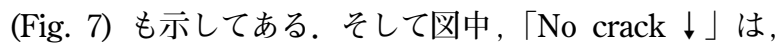
研磨前にはき裂は観察されなかったことを意味している。 図から明らかなように，き裂は化合物層に接した母材部 で発生するが，き裂の発生時期は表面で観察された以上 に遅れている。 また，表面観察で求めたき裂が短いとこ ろでのき裂伝ぱ速度の低下は，実際のき裂長さで評価す ればさらに遅くなることがわかる。これには，化合物層 が割れるまでは大気遮断効果をもつこと，また変形が拘 束されることも要因として考えられる.

以上のことから，前報で用いた化合物層が $4 \mu \mathrm{m}$ （N500 材）の場合も，き裂の起点は化合物層に接する母材の表 面である可能性があるので，上記と同様の手法で内部き 裂の確認を行った。 その結果，写真は省略するが，今回

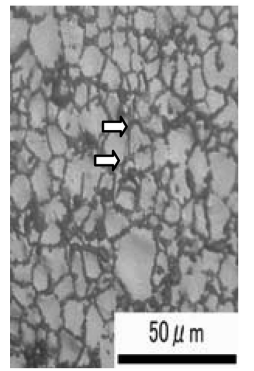

(b-1) Before EP

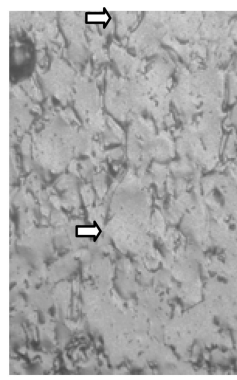

(b-2) After EP

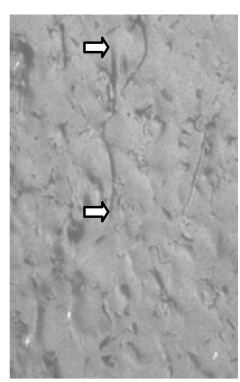

(b-3) After EP $(\mathrm{t} \simeq 30 \mu \mathrm{m})$ $a=0.075(\mathrm{~mm})$ $a=0.080$

(b) $N=3.5 \times 10^{5}$ (cycles)

Fig. 11 Surface states of fatigued specimen before and after removing surface layer by electro-polishing. (MN570, $\sigma_{\mathrm{a}}=800 \mathrm{MPa}, \Rightarrow$ crack tip, $\mathrm{t}:$ removed depth, $\leftrightarrow$ axial direction). 


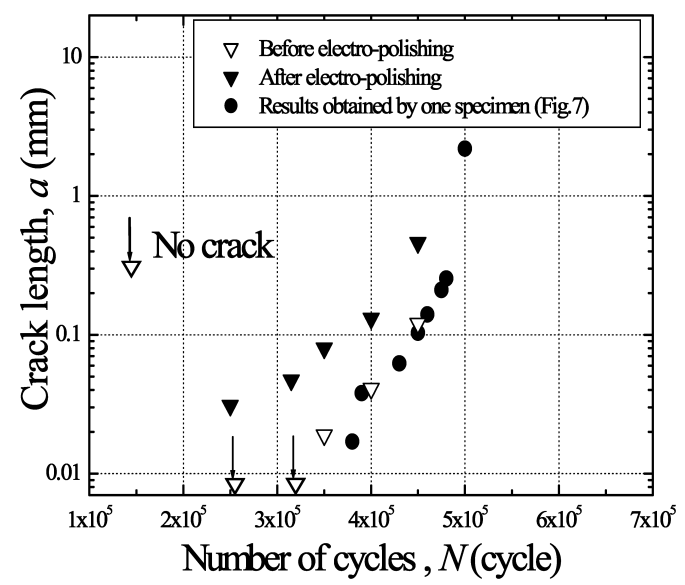

Fig. 12 Growth curves of crack initiated beneath compound layer obtained by electro-polishing. $\left(\mathrm{MN} 570, \sigma_{\mathrm{a}}=800 \mathrm{MPa}\right)$.

の MN570 材と同様に，き裂は化合物層下の母材部で発 生したことが確認された。

\section{4 結}

Alloy 718 にラジカル窒化を行えば，化合物層が形成さ れ，それにより疲労き裂の発生が抑制され，疲労強度は 上昇する。そしてき裂発生の抑制は，化合物層が厚い方 が効果的である。しかし化合物層を厚くするには, 窒化 の温度を高く, 時間を長くする必要があり, その場合, 母材は軟化する. 本研究では, Alloy 718 のラジカル窒化 条件として，母材の軟化を生じさせずに化合物層を厚く するための適切な時効処理と窒化処理の各条件を選ぶこ とにより, より高い疲労強度を得ること, またその場合 のき裂発生箇所を明らかにすることを目的に回転曲げ疲 労試験を行った。そして得られた結果を，先に報告した 通常の二段時効した時効材に同じ窒化条件で処理した材 料の結果と比較した. 主な結果をまとめると以下の通り である。

（1）窒化の温度と時間を考慮した時効条件を選ぶこと により，母材の軟化を抑制し疲労特性を改善することが できた.

（2）窒化材のき裂は，化合物層に接する母材の表面で 発生し，その後表面き裂となる。そして化合物層に沿う き裂の伝ぱはぜい性的で直線的であるが, 数十 $\mu \mathrm{m}$ 程度 の短い長さから徐々に長くなる安定成長であった.

（3）化合物層下の母材部で発生したき裂は，化合物に より発生時期が遅れると共にき裂が短い段階で伝ぱ速度 の低下も生じた.

\section{参 考 文 献}

1) T. Bell and N. L. Loh, "The fatigue characteristics of plasma nitrided three pct Cr-Mo steel”, Journal of Heat Treating, Vol.2, No.3, pp.232-237 (1982).

2 ) K. Shiozawa, T. Ohtani, S. Nishino, M. Okane, S. Kawamura and T. Naganawa, "Fatigue strength and subsurface crack growth properties of plasma assisted duplex surface treated tool steel (SKD61)", Transaction of the Japan Society of
Mechanical Engineers, A, Vol.64, No.628. pp.3050-3057 (1998).

3 ) W. Karlinski, J. Tacikowski and K. Wojtyra, "Fatigue strength of nitrided $18 \mathrm{Ni} 250$ and $18 \mathrm{Ni} 300$ grade maraging steels”, Surface Engineering, Vol.15, No.6, pp.483-489 (1999).

4 ) K. Tokaji and S. Takahashi, "Fatigue strength and subsurface crack initiation in nitrided low alloy steel SCM 435", Transaction of the Japan Society of Mechanical Engineers, A, Vol.67, No.653, pp.86-93 (2001).

$5)$ N. Kawagoishi, K. Fukada, K. Morino, Q. Chen and E. Kondo "Improvement of fatigue strength of maraging steel by nitriding", Transaction of the Japan Society of Mechanical Engineers, A, Vol.67, No.654, pp.314-320 (2001).

$6)$ K. Fukada, N. Kawagoishi, H. Muranaka, K. Morino and E. Kondo, "Fatigue strength of nitrided dies steel at elevated temperature", Transaction of the Japan Society of Mechanical Engineers, A, Vol.67, No.657, pp.912-918 (2001).

7 ) K. Morino, N. Kawagoishi. K. Fukada, QY. Wang and E. Kondo, "Influence of compound layer on fatigue strength of radical nitrided SNCM439 steel”, Transaction of the Japan Society of Mechanical Engineers, A, Vol.69, No.686, pp.14901496 (2003).

8) K. Yamane, N. Kawagoishi, Y. Maeda, K. Morino, F. Nishimura and M. Oki, "Effect of surface treatment on fatigue strength of martensitic type stainless steel SUS420J2", Journal of the Society of Materials Science, Japan, Vol.59, No.7, pp.521-526 (2010).

9) K. Yamane, K. Morino, K. Fukada and N. Kawagoishi, "Improvement of wear and fatigue properties of alloy 718 by radical nitriding”, Journal of the Society of Materials Science, Japan, Vol.59, No.11, pp.815-820 (2010).

10) K. Yamane, K. Morino, N. Kawagoishi and K. Fukada, "Fatigue properties of radical nitrided Alloy 718 at elevated temperature under push-pull loading", Journal of the Society of Materials Science, Japan, Vol.59, No.11, pp.821-826 (2010).

11) K. Yamane, A. Ohta, N. Kawagoishi, K. Morino and K. Fukada, "Effect of radical nitriding on fatigue strength of alloy 718 under rotating bending", Journal of the Society of Materials Science, Japan, Vol.59, No.11, pp.827-832 (2010).

12) K. Fukada, "Surface modification of some kinds of steels by radical nitriding”, Journal of the Japan Society for Technology of Plasticity, Vol.40, No.464, pp.847-851 (1999).

13) T. Morita, M. Shimizu, K. Kawasaki and T. Chiba, "Fatigue properties of nitrided Ti-6Al-4V alloy", Transaction of the Japan Society of Mechanical Engineers, A, Vol.56, No.529, pp.1915-1919 (1990).

14) K. Tokaji, T. Ogawa, H. Shibata and Y. Kamiya, "The effect of gas nitriding on fatigue behavior of Ti-6Al-4V alloy", Transaction of the Japan Society of Mechanical Engineers, A, Vol.57, No.542, pp.2293-2299 (1991).

15) K. Shiozawa and S. Ohshima, "Effect of TiN coating on fatigue strength of carbon steel", Journal of the Society of Materials Science, Japan, Vol.39, No.442, pp.927-932 (1990). 